\title{
Aydın İli Sulu Koşullarında Bazı Tarla Bitkileri Ürün Desenlerinin Karşılaştırılması
}

\author{
Mehmet KALKINÇ ${ }^{1}$, Mustafa Ali KAYNAK ${ }^{* 2}$ \\ ${ }^{1}$ Aydın Adnan Menderes Üniversitesi, Ziraat Fakültesi, Aydın \\ ${ }^{2}$ Aydın Adnan Menderes Üniversitesi, Ziraat Fakültesi, Tarla Bitkileri Bölümü, Aydın
}

Öz: Bu çalışma Aydın ilinde sulu koşullarda bazı tarla bitkileri ürün desenlerinden uygun olanlarını belirlemek için yapıımıştır. Çalışma; Aydın Adnan Menderes Üniversitesi Ziraat Fakültesi Araştırma ve Uygulama Çiftliğinde, 2017 ve 2018 yıllarında tesadüf blokları deneme desenine göre üç tekerrürlü olarak yürütülmüştür.

Çalışmada, ana ürün pamuk, ana ürün dane mısır, ana ürün yer fıstığı, ikinci ürün pamuk + buğday, ikinci ürün dane mısır + buğday, silajlık mısır + silajık mısır + fiğ - arpa karışımı şeklinde altı farkı ürün deseni incelenmiştir. Çalışmada; incelenen ürün desenlerinin tamamının karlı olduğu, ürün desenlerinin münavebeli bir şekilde uygulanması gerektiği ve en karlı ürün deseninin ise ana ürün pamuk olduğu sonucuna varılmıştır.

Anahtar Kelimeler: üretim sistemi, ekonomik analiz, buğday, mısır, pamuk

Comparison of Crop Pattern Systems for Some Field Crops under Irrigated Conditions in Aydın Province

Abstract: The thesis was carried out to determine suitable crop patterns of some field crops under irrigated conditions in Aydin province. Field experiments of the study were conducted in the experimental field of Aydin Adnan Menderes University Agriculture Faculty Research Farm in Randomized Complete Block Design with three replications during 2017 and 2018 years.

In this study, six different crop patterns as main crop cotton, grain maize, peanut and as second crop cotton + wheat, corn + wheat, silage corn + silage corn + vetch - barley mixture were examined. In this study, it is concluded that the most profitable pattern is the main crop cotton and all product patterns examined are also profitable and product patterns should be applied alternately.

Keywords: crop product systems, economic analysis, wheat, corn, cotton

GiRiş

Tarımsal üretim genelde doğal koşullarda yapıldığı için özellikle iklim koşullarından kaynaklanan riskler taşımaktadır. Risk faktörünü finansman, teknoloji ve pazar da etkileyebilmektedir. Her ürünün bir üretim maliyeti vardır. Bu maliyetinde ekonomik yönden analiz edilmesi gerekir (Akçaöz, 2001). Ürünlerin satış fiyatı ile maliyeti arasındaki değişmeler, diğer bir deyişle elde edilen gelir durumuna göre üreticiler farklı üretim deseni arayışlarına gidebilmektedir (Gündüz ve Esengün, 2007).

Ülkemizde ürün desenlerinin oluşmasında karlılık büyük rol oynamaktadır. Aydın ilinde tarımın elverişliliği, ürün çeşitliliğine ve ikinci hatta üçüncü ürün yetiştiriciliğine uygun olması ve dört mevsim üretim yapılabilmesine olanak sağlamasına karşın sulu tarım yapılan alanlarda tarla bitkileri yetiştiriciliğinde büyük oranda yıl boyunca tek ürün (mono kültür) yetiştiriciliği yapılmaktadır. Pamuk ve mısır yetiştiriciliğinin karlı olduğu yıllarda üretici bu ürünleri önem vermekte üst üste aynı ürünü yetiştirmektedir. Bundan dolayı toprak verimliliği azalmakta elde edilen parasal değer ekonomik olmamaktadır. Tekniğine uygun bir şekilde hazırlanan ekim nöbeti sistemlerinde, tarlada yıl boyu üretim yapıldığı gibi zaman zaman tarla toprağı boş bırakılarak topraktan az miktarda besin maddesi kaldıran, kök ve anız artıklarıyla toprağı organik madde ve azot yönünden zenginleştiren yem bitkilerine yer verilmektedir. Bu şekilde, çok yönlü karlı bir üretim yapılmakta ve tarla toprağının verimlilik düzeyi artmaktadır. 2017 yılında, sulu koşullarda, Aydın ilinde en çok üretimi yapılan tarla bitkileri; buğday, pamuk, dane mısır, yerfıstığı ve silajlık mısırdır.

Bu çalışma; Aydın ilinde, sulu koşullarda, yıllık bitkisel üretim değerinin önemli bir bölümünü oluşturan ve bölgede üreticiler tarafından uygulanmakta olan pamuk, buğday ve mısır gibi tarla bitkilerinin oluşturduğu ürün desenlerinin ekonomik açıdan karşılaştırmasının yapılması ve üreticiye sunulabilecek ekonomik ürün deseni seçeneklerinin belirlenmesi amacıyla yapılmıştır.

\section{MATERYAL VE YÖNTEM}

\section{Materyal}

Çalışmada materyal olarak; ana ürün pamuk olarak Gloria çeşidi, ana ürün dane mısır olarak Dekalp 6630 çeşidi, ana ürün yer fıstığı olarak Nc7 çeşidi, silajlık mısır 1 olarak İnove çeşidi, silajlık mısır 2 olarak Hido çeşidi, ikinci ürün pamuk olarak Flash çeşidi, buğday olarak Ziyabey çeşidi, fiğ olarak Selçuk-99 çeşidi ve arpa olarak Akhisar 99 çeşidi kullanılmıştır.

\section{Yöntem}

Çalışma, Aydın Adnan Menderes Üniversitesi Ziraat

Sorumlu Yazar: mkaynak@adu.edu.tr. Bu çalışma yüksek lisans tez ürünüdür ve Aydın Adnan Menderes Üniversitesi Bilimsel Araştırma Projeleri Koordinatörlügünce desteklenmiştir (Proje No: ZRF17001)

Geliş Tarihi: 30 Ocak 2020

Kabul Tarihi: 4 Mayıs 2020 
Fakültesi Araştırma ve Uygulama Çiftliğinde sulanabilir tarım arazisinde, 2017-2018 yılı yetiştirme sezonunda yürütülmüştür. Çalışmada; ana ürün pamuk, ana ürün dane mısır, ana ürün yer fıstığı, ikinci ürün pamuk + buğday, ikinci ürün dane mısır + buğday ile silajlık mısır + silajlık mısır +fiğarpa karışımı olmak üzere altı farklı ürün deseni oluşturulmuştur.

Deneme, tesadüf blokları deneme desenine göre üç tekerrürlü olarak yürütülmüştür. Her parsel 25 metre uzunluğunda ve 8 sıradan oluşmuştur.

Aydın Adnan Menderes Üniversitesi Ziraat Fakültesi Toprak Bölümü laboratuvarının tahlil sonuçlarına göre ana ürün pamuğa, ikinci ürün pamuğa, pamuk sonrası buğdaya, mısır sonrası buğdaya, silajlık mısır 1'e ve silajlık mısır'2 ye 40 kg; ana ürün tane mısıra, ikinci ürün mısıra 50 şer kg 13:24.12 taban gübresi verilmiştir. Ana ürün yer fıstığına ise $40 \mathrm{~kg}$ DAP gübresi verilmiştir. Fiğ-arpa karışımın da 20 kg 15:15:15 taban gübresi verilmiştir. Üst gübresi olarak; ana ürün pamuk, ikinci ürün pamuk ve ana ürün yer fıstığına $30 \mathrm{~kg}$, pamuk sonrası buğday ve mısır sonrası buğdaya $20 \mathrm{~kg} \% 26$ lık amonyum nitrat, ana ürün pamuk ve ikinci ürün pamuğa $20 \mathrm{~kg}$ amonyum sülfat verilmiştir. Ayrıca üst gübresi olarak; ana ürün tane mısır, ikinci ürün tane mısır, silajlık mısır 1 ve Silajlık mısır 2 ye $40 \mathrm{~kg}$, pamuk sonrası buğday, mısır sonrası buğday ve fiğ-arpa karışımına $15 \mathrm{~kg}$ üre verilmiştir. Ayrıca ana ürün yer fıstığına $20 \mathrm{~kg}$ potasyum nitrat verilmiştir. Tüm ürünlerde taban gübresi, toprak hazırlığı döneminde (ekim öncesi) verilmiştir. Üst gübre ise iki defada olmak üzere; ana ürün pamuk, ana ürün mısır, ana ürün yer fıstığın ve silajlık mısır 1'e 2017 Haziran ayında verilmiştir.

Ekim işlemi, silajlık mısır 1'e 15.04.2017 tarihinde, ana ürün pamuk ve ana ürün dane mısır da 05.05.2017 tarihinde, ikinci ürün pamuk ve ikinci ürün mısır da 10.06.2017 tarihinde, silajlık mısır 2, 21.07.2017 tarihinde, pamuk sonrası buğday, mısır sonrası buğday ve fiğ arpa karışımı 27.11.2017 tarihinde yapılmıştır. Ekimi yapılan bitkilerin sıra arası ve sıra üzeri uzaklıkları Çizelge 1'de verilmiştir. Çizelge 1'de görüleceği üzere yazlık ekim yapılan ürünlerde sıra arası mesafesi $70 \mathrm{~cm}$, kışlık ekim yapılan ürünlerde sıra arası mesafesi $13 \mathrm{~cm}$ dir. Ürünlerin sıra üzeri mesafeleri; ana ürün pamukta ve ikinci ürün pamukta $3,5 \mathrm{~cm}$, ana ürün dane mısırda $18 \mathrm{~cm}$ ana ürün yer fıstığında $12 \mathrm{~cm}$, ikinci ürün dane mısırda $17 \mathrm{~cm}$, silajlık mısırlarda $16 \mathrm{~cm}$ buğday ve fiğ arpa karışımında $8 \mathrm{~cm}$ dir.

Nisan ayı içerisinde ekimi yapılan bitkilerin Mayıs başında ara tekli ve frezeli çapalama işlemi yapılmıştır. Mayıs ayı içerisinde ekimi yapılan bitkilerin ise Haziran ayı sonunda ara işlemleri yapılmıştır. Pamuk ve yer fıstığında çapalama işlemi ile birlikte aşılama ve seyreltme çalışması yapılmıştır. Pamukta seyreltme sonrası sıra üzeri mesafesi $15 \mathrm{~cm}$ 'ye düşürülmüştür.
Çizelge 1. Denemede ekimi yapılan bitkilerin sıra arası ve sıra üzeri mesafeleri $(\mathrm{cm})$

\begin{tabular}{lll}
\hline Bitki & $\begin{array}{l}\text { Ekim Normu } \\
\text { (cm) }\end{array}$ & $\begin{array}{l}\text { Bitki Sıklı̆ı } \\
\text { (Bitki/da) }\end{array}$ \\
\hline Ana ürün pamuk & $70 \times 15$ & 9,524 \\
Ana ürün tane mısır & $70 \times 18$ & 7,936 \\
Ana ürün yer fıstığı & $70 \times 12$ & 11,905 \\
İkinci ürün pamuk & $70 \times 15$ & 9,524 \\
İkinci ürün tane mısır & $70 \times 17$ & 8,403 \\
Pamuk sonrası buğday & $13 \times 0,8$ & 550,000 \\
Mısır sonrası buğday & $13 \times 0,8$ & 550,000 \\
Silajlık mısır 1 & $70 \times 16$ & 8,928 \\
Silajlık mısır 2 & $70 \times 16$ & 8,928 \\
Fiğ-arpa karışımı & $13 \times 0,8$ & 550,000 \\
\hline
\end{tabular}

Denemede, 20 Haziran 2017 tarihinde silajlık mısır 1'in 1.sulaması yapılmıştır.2 Temmuz 2017 tarihinde, ana ürün dane mısır, ana ürün yer fıstığı ve ikinci ürün dane mısır da 1. Sulama, silajlık mısır 1 de 2. sulama yapılmıştır. 22 Temmuz 2017 tarihinde silajlık mısır 2 hariç denemede kurulan tüm parseller sulaması yapılmıştır. 10 Ağustos 2017 tarihinde ana ürün pamukta 2. sulama, silajlık mısır 2 ve ikinci ürün pamuk' da 1 . sulama diğer parsellerde 3 . sulaması yapılmıştır. 25 Ağustos 2017 tarihinde ana ürün pamukta 3. sulama, ikinci ürün pamuk ve silajlık mısır 2 de 2. sulama diğer parsellerde 4. sulamalar yapılmıştır. İkinci ürün pamuk ve silajlık mısır 2'de 12 Eylül tarihinde son kez sulama yapılmıştır.

Yetiştirme sürecince pamukta karşılaşılan Bemisia tabaci (Tütün Beyazsineği), Thrips tabaci (Tütün tripsi), Aphis gossypii (Pamuk yaprak biti), kırmızı örümcekler ve Helicoverpa armigera (pamuk yeşil kurdu) için yer fıstığında kırmızı örümcek için karşılaşılan zararlılara karşı kimyasal mücadele yapılmıştır. Ayrıca mısırda yabancı ot ilaçlaması da yapılmıştır.

Denemede Nisan ayı içerisinde ekimi yapılan 1. ekim silajık mısırda hasat işlemleri 08 Temmuz 2017 tarihinde gerçekleştirilmiştir. Yine Mayıs ayı içerisinde ekimi yapılan 1. ürün tanelik mısır 15 Eylül 2017 de,1. Ürün pamuk 10 Ekim 2017 de ve yer fıstığı 1 Kasım 2017'de hasatları yapılmıştır. Haziran ayında ekimi yapılan 2 . ürün pamuk 1 Aralık 2017 de, 2. ürün tanelik mısır da 25 Ekim 2017 tarihinde hasat gerçekleşmiştir. Temmuz ayı içerisinde ekimi yapılan 2. ürün silajlık mısırın 13 Kasım 2017 tarihinde hasadı gerçekleştirilmiştir. Kasım ayı içerisinde ekimi yapılan buğdaylar 1 Haziran 2018 de, fiğ arpa karışımı ise 5 Mayıs 2018 de hasat yapılmıştır.

\section{İncelenen Özellikler}

Verim (kg/da):Hasat sonrası, her bitki için dekara verim değerleri ayrı ayrı saptanmıştır. 
Bitkilerin üretici satış fiyatları (TL/kg): Ticaret borsası, ziraat odası ve TMO'nun rayiç fiyatları baz alınarak hesaplanmıştır.

Bitkilerin gayrisafi üretim değeri (TL/da):Aşağıdaki formüle göre hesaplanmıştır (Özçelik ve ark., 2011).

Bitkilerin gayrisafi üretim değeri $(\mathrm{TL} / \mathrm{da})=$ Dekara Verim $\mathrm{x}$ Üretici Satış Fiyatı

Bitkilerin üretim masrafı (TL/da): Sabit ve değişken masraflardan meydana gelmektedir. Sabit masraflar, üretim miktarına bağlı olmayan, değişken masraflar ise üretim miktarına bağlı olarak artan ya da azalan masraflardır (Özçelik ve ark., 2011). Değişken masraflardan tohum, gübre, zirai ilaç ihtiyaç kadar satın alınmıştır. Ekim için toprak hazırlığı, çapalama, sulama ve hasat bedelinin belirlenmesinde rayiç fiyatlar dikkate alınmıştır. Ayrıca değişken masraflar faizi (\%5) hesaplanmıştır. Toplam sabit masraflar tüm bitkilerde aynı olduğu için dikkate alınmamıştır.

Bitkilerin birim maliyeti (TL/kg): Aşağıdaki formüle göre hesaplanmıştır (Özçelik ve ark., 2011).

Bitkilerin birim maliyeti (TL/kg)= Üretim Masrafı / Verim

Bitkilerinin brüt karı (TL/da): Aşağıdaki formüle göre hesaplanmıştır (Özçelik ve ark., 2011).

Bitkilerinin brüt karı $(\mathrm{TL} / \mathrm{da})=$ Gayrisafi Üretim Değeri Toplam Değişken Masraf.

Bitkilerin nispi karı: Aşağıdaki formüle göre hesaplanmıştır (Özçelik ve ark., 2011).

Bitkilerin nispi karı= Gayrisafi Üretim Değeri/Toplam Değişken Masraf.

\section{BULGULAR VE TARTIŞMA}

Ürünlerin ve ürün desenlerinin ekonomik yönden değerlendirilmesi:

Aydında sulu koşullarda mevcut tarla bitkileri ürün desenlerinin karşılaştırılması için ekonomik değerlendirme yapılmıştır. Ekonomik olarak yapılan değerlendirme çalışmasında bitkilerin verimi, satış fiyatı, gayrisafi üretim değeri, üretim masrafı, birim maliyeti, brüt karı ve nispi karı aşağıda ayrı ayrı incelenmiştir.

\section{Bitkilerin Verim Değerleri (kg/da)}

Denemede yetiştirilen bitkilerin verim değerleri Çizelge 2'de verilmiştir. Çizelge 2'de görüldüğü üzere kurulan denemeden $527 \mathrm{~kg} /$ da ana ürün pamuk, $1413 \mathrm{~kg} / \mathrm{da}$ ana ürün dane mısır, 444 kg/da ana ürün yer fıstığı, 360 kg/da ikinci ürün pamuk, $1080 \mathrm{~kg} /$ da ikinci ürün dane mısır, 477 $\mathrm{kg} / \mathrm{da}$ pamuk sonrası buğday, $+509 \mathrm{~kg} / \mathrm{da}$ buğday samanı, $498 \mathrm{~kg} /$ da mısır sonrası buğday $+562 \mathrm{~kg} / \mathrm{da}$ buğday samanı, $5525 \mathrm{~kg} /$ da silajlık mısır 1, 3601 kg/da silajlık mısır 2, 722 $\mathrm{kg} / \mathrm{da}$ fiğ arpa karışımı elde edilmiştir. Denemeden en yüksek verim silajlık mısır 1 , en düşük verim ise ikinci ürün pamuktan elde edilmiştir.

İkinci ürün pamuktan elde edilen dekara verim değeri; Karademir ve ark. (2005) kütlü pamuk verimi ortalama 368.00 ile $407.63 \mathrm{~kg} / \mathrm{da}$ arasında değerlere ulaşmış olup denemeden alınan verim değerlerle uyum sağlamıştır.

Ana ürün pamukta elde edilen dekara verim değerleri; Albayrak (2014) en düşük kütlü pamuk verimi 500 kg olarak, en yüksek 625 kg kütlü verimi olarak saptamıştır. Ortalama kütlü pamuk verimi ise dekarda $561 \mathrm{~kg}$ olarak bulmuştur. $\mathrm{Bu}$ değerler denemeden alınmış olan denemeden alınan verim değeriyle uyum sağlamaktadır.

Çizelge 2. Ürünlerin ve ürün desenlerinin ekonomik açıdan karşılaştırılması

\begin{tabular}{|c|c|c|c|c|c|c|c|}
\hline Bitki & $\begin{array}{l}\text { Verim } \\
\text { (kg/da) }\end{array}$ & $\begin{array}{l}\text { Satış } \\
\text { Fiyatı } \\
\text { (TL/kg) }\end{array}$ & $\begin{array}{l}\text { Gayrisafi } \\
\text { Üretim Değeri } \\
\text { (TL/da) }\end{array}$ & $\begin{array}{l}\text { Üretim } \\
\text { Masrafı } \\
\text { (TL/da) }\end{array}$ & $\begin{array}{l}\text { Birim } \\
\text { Maliyeti } \\
\text { (TL/kg) }\end{array}$ & $\begin{array}{l}\text { Brüt } \\
\text { Kar } \\
\text { (TL/da) }\end{array}$ & $\begin{array}{l}\text { Nispi } \\
\text { Kar }\end{array}$ \\
\hline Ana ürün pamuk & 527 & 3.880 & 2044 & 744.62 & 1.41 & 1300 & 2.74 \\
\hline Ana ürün dane mısır & 1413 & 0.805 & 1137 & 350.44 & 0.24 & 786.5 & 3.24 \\
\hline Ana ürün yer fıstığı & 444 & 4.037 & 1792 & 667.48 & 1.50 & 1124.5 & 2.68 \\
\hline İkinci ürün pamuk & 360 & 3.511 & 1263 & 685.56 & 1.90 & 577.4 & 1.84 \\
\hline İkinci ürün dane mısır & 1080 & 0.810 & 875 & 342.51 & 0.31 & 532.5 & 2.55 \\
\hline \multirow{2}{*}{$\begin{array}{l}\text { Pamuk sonrası buğday (dane+ } \\
\text { saman) }\end{array}$} & 477 & 1.135 & 541 & 291.37 & 0.61 & \multirow{2}{*}{473.1} & \multirow{2}{*}{2.46} \\
\hline & 509 & 0.50 & 254 & 30.54 & 0.06 & & \\
\hline \multirow{2}{*}{$\begin{array}{l}\text { Mısır sonrası buğday (dane } \\
\text { +saman) }\end{array}$} & 498 & 1.134 & 564 & 296.17 & 0.59 & \multirow{2}{*}{515.1} & \multirow{2}{*}{2.56} \\
\hline & 562 & 0.50 & 281 & 33.72 & 0.06 & & \\
\hline Silajlık mısır 1 & 5525 & 0.166 & 917 & 375.24 & 0.06 & 541.7 & 2.44 \\
\hline Silajlık mısır 2 & 3601 & 0.155 & 558 & 371.49 & 0.10 & 186.5 & 1.50 \\
\hline Fiğ-arpa karışımı & 722 & 0.605 & 436 & 211.15 & 0.29 & 224.8 & 2.06 \\
\hline
\end{tabular}


Uzun ve ark.(2005) Sulu koşullarda yetiştirilmiş ana ürün mısır verimini $1464.6 \mathrm{~kg} /$ da olarak tespit etmişlerdir ve bu bulgular denemeden alınmış olan değerlerle uyum sağlamaktadır. Fakat Karaşahin ve Sade (2011) 1734.50 $\mathrm{kg} / \mathrm{da}$ almış olduğu verim değeri denemeden alınmış olan verim değerinden yüksektir.

Yer fıstığından elde edilen verim değeri; Kadiroğlu (2012) $424.2 \mathrm{~kg}$ olarak almış olduğu verim değeri denemeden elde edilen verim değeri ile uyum göstermiştir. Söğüt (1996) 306.5 kg/ da aldığı verim değeri denemeden elde edilen verim değerinden düşüktür.

İkinci ürün dane mısırda elde edilen verim değeri; İdikut ve Kara (2013) 1290 kg/da elde etmiş olduğu verim değerleri denemeden elde edilen verim değeri ile uyum sağlamıştır.

Silajlık mısırda elde edilen verim değerleri; Öztürk ve ark. (2011) 5793.9 kg/da aldıkları verim değerleri ile uyum sağlamaktadır.

Buğdayda elde edilen verim değerleri; Kaya ve ark. (2005) ekmeklik buğdayda ortalama olarak $510.4 \mathrm{~kg} / \mathrm{da}$ aldıkları verim değerleri ile uyum sağlamaktadır. Egesel ve ark. (2009) Nina ve Tina çeşitlerinden (394.8 ve 388.6 kg/da) elde edilmiş olan verim değerleri ise denemeden elde edilen verim değerinden düşüktür.

Fiğ-arpa karışımından elde edilen verim değerleri; Arslan (2012) 253.89-462.06 kg/da arasında elde edilen verim değerlerinin denemeden elde edilen verim değerlerinden düşüktür. Avcıoğlu (1979) elde ettiği kuru ot verimi (791.5 $\mathrm{kg} / \mathrm{da}$ ) değerleriyle ise uyum sağlamaktadır.

\section{Bitkilerin Üretici Satış Fiyatları (TL/kg)}

Bitkilerin hasat dönemi destekleme ve satış fiyatları Çizelge 3 'de gösterilmiştir.

Çizelge 3. Bitkilerin hasat dönemi destekleme ve satış fiyatı $(\mathrm{TL} / \mathrm{kg})$

\begin{tabular}{llll}
\hline & $\begin{array}{l}\mathbf{2 0 1 7} \text { Yılı } \\
\text { Fark } \\
\text { Ödemesi } \\
\text { Desteği } \\
\text { (TL/Kg) }\end{array}$ & $\begin{array}{l}\text { Üretici } \\
\text { Satış } \\
\text { Fiyatı } \\
\text { (TL/Kg) }\end{array}$ & $\begin{array}{l}\text { Toplam } \\
\text { Fiyatı } \\
\text { (TL/Kg) }\end{array}$ \\
\hline Ana ürün pamuk & 0.880 & 3.00 & 3.880 \\
Ana ürün dane mısır & 0.045 & 0.76 & 0.805 \\
Ana ürün yer fıstığı & 0.037 & 4.00 & 4.037 \\
Ikinci ürün pamuk & 0.911 & 2.60 & 3.511 \\
İkinci ürün dane mısır & 0.050 & 0.76 & 0.810 \\
Pamuk sonrası buğday & 0.085 & 1.05 & 1.135 \\
Mısır sonrası buğday & 0.084 & 1.05 & 1.134 \\
Silajlık mısır 1 & 0.0163 & 0.15 & 0.166 \\
Silajlık mısır 2 & 0.0250 & 0.13 & 0.155 \\
Fiğ-arpa karışımı & 0.055 & 0.55 & 0.605 \\
\hline
\end{tabular}

Tarım ve Orman Bakanlığı'nın Tarım Havzalarını Destekleme Modeline göre 2017 Yılı Fark Ödemesi desteği kapsamında mazot ve kimyevi gübre desteklemeleri dahil Aydın Koçarlı ilçesinde ana ürün pamukta $0.880 \mathrm{TL} / \mathrm{kg}$, ana ürün dane mısırda $0.045 \mathrm{TL} / \mathrm{kg}$, Ana ürün yer fıstığında $0.037 \mathrm{TL} / \mathrm{kg}$, ikinci ürün pamukta $0.911 \mathrm{TL} / \mathrm{kg}$, ikinci ürün tane mısırda $0.050 \mathrm{TL} / \mathrm{kg}$, pamuk sonrası buğdayda $0.085 \mathrm{TL} / \mathrm{kg}$, mısır sonrası buğdayda $0.084 \mathrm{TL} / \mathrm{kg}$, silajlık mısır 1'de 0.0163 $\mathrm{TL} / \mathrm{kg}$, silajılk mısır 2'de $0.0250 \mathrm{TL} / \mathrm{kg}$, fiğ-arpa karışımında $0.055 \mathrm{TL} / \mathrm{kg}$ destekleme verilmiştir.

Çizelge 2 ve 3'de, denemede yetiştirilen bitkilerin hasat dönemi sonrası satış fiyatına fark ödemesi destek miktarları da ilave edildiğinde birim fiyatı en yüksek 4.037 TL ile ana ürün yer fıstığıdır. Ana ürün yer fıstığını ana ürün pamuk 3.88 TL ve ikinci ürün pamuk 3.511 TL takip etmektedir.

Birim fiyatı en düşük deneme bitkisi silajlık mısır 20.155 TL ve fiğ-arpa karışımı 0.605 TL'dir.

\section{Bitkilerin Gayrisafi Üretim Değeri (TL/da)}

Bitkilerin gayrisafi üretim değeri Çizelge 2'de gösterilmiştir. Çizelge 2 incelendiğinde gayrisafi üretim değeri en yüksek bitki 2044 TL ile ana ürün pamuktur. Ana ürün pamuğa 1792 TL ile yer fıstığı ve 1263 TL ile ikinci ürün pamuk takip etmektedir. Gayrisafi üretim değeri en düşük bitkiler ise pamuk sonrası buğday 795 TL, silajlık mısır 2558 TL ve fiğarpa karışımı 436 TL'dir.

\section{Bitkilerin Üretim Masrafları (TL/da)}

Bitkilerin üretim masrafı Çizelge 2'de ve her bitki için yapılan değişken masrafları Çizelge 4 ve 5'de gösterilmiştir. Zirai mücadele ilaç bedeli ve hasat bedeli yüksek olmasında dolayı üretim masrafı en yüksek olan bitki $744.62 \mathrm{TL} / \mathrm{da}$ ile ana ürün pamuktur. Ana ürün pamukta diğer ürünlere göre ilaçlama sayısının fazla olması ilaç fiyatlarının yüksek olması ve dekarda hasat ücretinin yüksek olması nedeniyle ana ürün pamuk bitkisinin üretim masrafları en yüksek olan bitki olmasını sağlamıştır. Yine aynı şekilde en yüksek üretim masraflarında ikinci sıraya yukarıda belirtilen nedenlerden dolayı $685.62 \mathrm{TL} / \mathrm{kg}$ ile ikinci ürün pamuk gelmektedir. Toplam değişken masrafı en düşük bitki $215.11 \mathrm{TL} /$ da ile fiğarpa karışımı gelmektedir.

\section{Bitkilerin Birim Maliyeti (TL/kg)}

Çalışmada üretim masrafının bitkilerin verimlerine oranları hesaplanarak birim maliyetleri Çizelge 2'de gösterilmiştir.

Birim maliyeti en yüksek bitki $1.9 \mathrm{TL} / \mathrm{kg}$ ile ikinci ürün pamuktur. Nedeni ise verim düşüklüğüdür. Ana ürün pamukta üretim masraflarının yüksek olması birim maliyetinin yüksek çıkmasına neden olmuştur. Birim maliyeti en düşük bitki ise silajlık mısır 1 ve silajık mısır 2'dir. 
Çizelge 4. Ana ürün mısır, ana ürün pamuk, ana ürün yer fıstığı, ikinci ürün pamuk, ikinci ürün dane mısır bitkilerine ait üretim masrafları tablosu

\begin{tabular}{|c|c|c|c|c|c|c|c|c|c|c|c|c|c|c|c|}
\hline \multirow[b]{2}{*}{ DEĞiŞKEN MASRAFLAR } & \multicolumn{3}{|c|}{ Ana ürün pamuk } & \multicolumn{3}{|c|}{ Ana ürün dane mısır } & \multicolumn{3}{|c|}{ Ana ürün yer fıstığı } & \multicolumn{3}{|c|}{ İkinci ürün pamuk } & \multicolumn{3}{|c|}{ İkinci ürün dane mısır } \\
\hline & 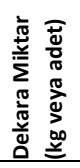 & 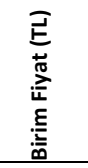 & 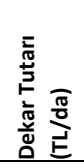 & 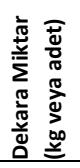 & 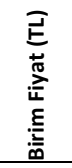 & 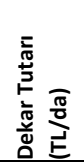 & 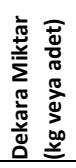 & 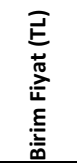 & 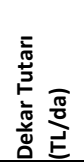 & 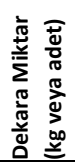 & 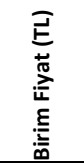 & 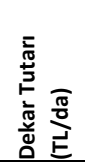 & 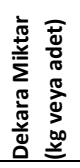 & 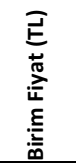 & 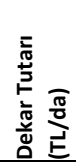 \\
\hline Tohum Bedeli & 4.00 & 10.00 & 40.00 & 2.52 & 23.30 & 57.96 & 8.00 & 8.00 & 64.00 & 4.00 & 8.00 & 32.00 & 2.52 & 20.00 & 50.40 \\
\hline Kimyevi Gübre Bedeli & 90.00 & 1.30 & 117.0 & 90.00 & 1.52 & 136.80 & 90.00 & 2.14 & 192.6 & 90.00 & 1.30 & 117.00 & 90.00 & 1.52 & 136.80 \\
\hline Gübreleme İşçiliği & 3.00 & 8.00 & 24.00 & 2.00 & 8.00 & 16.00 & 3.00 & 8.00 & 16.00 & 3.00 & 8.00 & 24.00 & 2.00 & 8.00 & 16.00 \\
\hline Zirai Mücadele İlaç Bedeli & 6.00 & 22.17 & 133.07 & 1.00 & 12.00 & 12.00 & 2.00 & 15.05 & 30.10 & 4.00 & 25.46 & 101.87 & 1.00 & 12.00 & 12.00 \\
\hline Zirai Mücadele İşçiliği & 6.00 & 8.00 & 48.00 & 1.00 & 8.00 & 8.00 & 2.00 & 8.00 & 16.00 & 4.00 & 8.00 & 32.00 & 1.00 & 8.00 & 8.00 \\
\hline Sürüm & 1.00 & 15.00 & 15.00 & 1.00 & 15.00 & 15.00 & 1.00 & 15.00 & 15.00 & 1.00 & 15.00 & 15.00 & 1.00 & 15.00 & 15.00 \\
\hline Diskaro & 3.00 & 4.00 & 12.00 & 3.00 & 4.00 & 12.00 & 3.00 & 4.00 & 12.00 & 3.00 & 4.00 & 12.00 & 3.00 & 4.00 & 12.00 \\
\hline Makinalı Çapa & 4.00 & 12.00 & 48.00 & 3.00 & 12.00 & 36.00 & 4.00 & 12.00 & 48.00 & 4.00 & 12.00 & 48.00 & 3.00 & 12.00 & 36.00 \\
\hline Ekim/Dikim & 1.00 & 12.00 & 12.00 & 1.00 & 12.00 & 12.00 & 1.00 & 12.00 & 12.00 & 1.00 & 12.00 & 12.00 & 1.00 & 12.00 & 12.00 \\
\hline El Çapası & 2.00 & 55.00 & 110.00 & - & - & - & 2.00 & 55.00 & 110.00 & 2.00 & 55.00 & 110.00 & - & - & - \\
\hline Hasat & 1.00 & 150.00 & 150.00 & 1.00 & 28.00 & 28.00 & 3.00 & 40.00 & 120.00 & 1.00 & 150.00 & 150.00 & 1.00 & 28.00 & 28.00 \\
\hline Balyalama & - & - & - & - & - & - & - & - & - & - & - & & - & - & - \\
\hline Değişken Masraflar Toplamı & - & - & 709.17 & - & - & 333.76 & - & - & 635.70 & - & - & 653.87 & - & - & 326.2 \\
\hline Değişen Masraflar Faizi (\%5) & - & - & 35.45 & - & - & 16.68 & - & - & 31.78 & - & - & 31.69 & - & - & 16.31 \\
\hline $\begin{array}{l}\text { TOPLAM DEĞIŞEN } \\
\text { MASRAFLAR (TDM) }\end{array}$ & - & - & 744.62 & - & - & 350.44 & - & - & 667.48 & - & - & 685.56 & - & - & 342.51 \\
\hline
\end{tabular}

Çizelge 5. Pamuk sonrası buğday, mısır sonrası buğday, silajlık mısır 1, silajlık mısır 2, fiğ-arpa karışımı bitkilerine ait üretim masrafları tablosu

\begin{tabular}{|c|c|c|c|c|c|c|c|c|c|c|c|c|c|c|c|}
\hline \multirow[b]{2}{*}{$\begin{array}{l}\text { DEĞişKEN } \\
\text { MASRAFLAR }\end{array}$} & \multicolumn{3}{|c|}{ Pamuk sonrası buğday } & \multicolumn{3}{|c|}{ Mısır sonrası buğday } & \multicolumn{2}{|c|}{ Silajlık mısır 1} & \multicolumn{4}{|c|}{ Silajlık mısır 2} & \multicolumn{3}{|c|}{ Fiğ-arpa karışımı } \\
\hline & 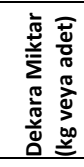 & 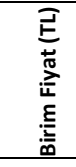 & 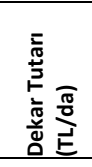 & 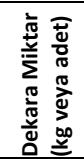 & 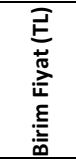 & 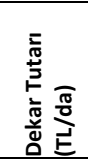 & 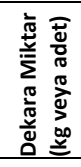 & 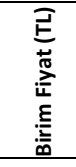 & 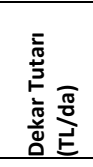 & 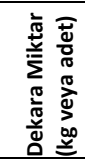 & 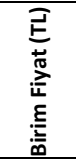 & 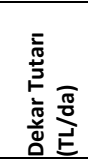 & 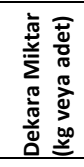 & 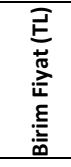 & $\begin{array}{l}\frac{5}{5} \\
\stackrel{5}{5} \\
\frac{\pi}{7} \\
\frac{\pi}{0} \\
\frac{1}{0}\end{array}$ \\
\hline Tohum Bedeli & 25.00 & 1.40 & 35.00 & 25.00 & 1.40 & 35.00 & 2.70 & 14.66 & 39.58 & 2.70 & 13.33 & 36.00 & 16.00 & 2.40 & 38.40 \\
\hline $\begin{array}{l}\text { Kimyevi Gübre } \\
\text { Bedeli }\end{array}$ & 80.00 & 1.40 & 112.00 & 80.00 & 1.40 & 112.00 & 90.00 & 1.52 & 136.80 & 90.00 & 1.52 & 136.80 & 35.00 & 1.35 & 47.25 \\
\hline Gübreleme İşçiliği & 3.00 & 8.00 & 24.00 & 3.00 & 8.00 & 24.00 & 2.00 & 8.00 & 16.00 & 2.00 & 8.00 & 16.00 & 2.00 & 8.00 & 16.00 \\
\hline $\begin{array}{l}\text { Zirai Mücadele İlaç } \\
\text { Bedeli }\end{array}$ & 1.00 & 7.00 & 7.00 & 1.00 & 7.00 & 7.00 & 1.00 & 12.00 & 12.00 & 1.00 & 12.00 & 12.00 & - & - & - \\
\hline $\begin{array}{l}\text { Zirai Mücadele } \\
\text { İşçiliği }\end{array}$ & 1.00 & 8.00 & 8.00 & 1.00 & 8.00 & 8.00 & 1.00 & 8.00 & 8.00 & 1.00 & 8.00 & 8.00 & - & - & - \\
\hline Sürüm & 1.00 & 15.00 & 15.00 & 1.00 & 15.00 & 15.00 & 1.00 & 15.00 & 15.00 & 1.00 & 15.00 & 15.00 & 1.00 & 15.00 & 15.00 \\
\hline Diskaro & 3.00 & 4.00 & 12.00 & 3.00 & 4.00 & 12.00 & 3.00 & 4.00 & 12.00 & 3.00 & 4.00 & 12.00 & 3.00 & 4.00 & 12.00 \\
\hline Makinalı Çapa & - & - & - & - & - & - & 3.00 & 12.00 & 36.00 & 3.00 & 12.00 & 36.00 & - & - & - \\
\hline Ekim/Dikim & 1.00 & 12.00 & 12.00 & 1.00 & 12.00 & 12.00 & 1.00 & 12.00 & 12.00 & 1.00 & 12.00 & 12.00 & 1.00 & 12.00 & 12.00 \\
\hline El Çapası & - & - & - & - & - & - & - & - & - & - & - & - & - & - & - \\
\hline Hasat & 1.00 & 25.00 & 25.00 & 1.00 & 25.00 & 25.00 & 1.00 & 70.00 & 70.00 & 1.00 & 70.00 & 70.00 & 1.00 & 15.00 & 15.00 \\
\hline Balyalama & 509.00 & 0.06 & 30.54 & 22.48 & 0.06 & 33.72 & - & - & - & - & - & - & 772.00 & 0.07 & 54.04 \\
\hline $\begin{array}{l}\text { Değişken Masraflar } \\
\text { Toplamı }\end{array}$ & - & - & 279.54 & - & - & 283.72 & - & - & 357.38 & - & - & 353.80 & - & - & 209.69 \\
\hline $\begin{array}{l}\text { Değişen Masraflar } \\
\text { Faizi }(\% 5)\end{array}$ & - & - & 13.97 & - & - & 14.18 & - & - & 17.86 & - & - & 17.69 & - & - & 10.48 \\
\hline $\begin{array}{l}\text { TOPLAM DEĞIŞEN } \\
\text { MASRAFLAR (TDM) }\end{array}$ & - & - & 293.51 & - & - & 298.00 & - & - & 375.24 & - & - & 371.49 & - & - & 220.17 \\
\hline
\end{tabular}




\section{Bitkilerin Brüt Karı (TL/da)}

Çalışmada bitkilerin gayrisafi üretim değerinden toplam değişken masrafların çıkarılmasıyla elde edilen brüt karları Çizelge 2' de gösterilmiştir.

Brüt karı en yüksek bitki $1300 \mathrm{TL} /$ da ile ana ürün pamuktur. Dekardan alınan miktarının ve satış fiyatının diğer ürünlere göre yüksek olması nedeniyle bürüt karı en yüksek bitki olmuştur. Bürüt karı en düşük bitki ise $186.5 \mathrm{TL} /$ da ile silajlık mısır 2'dir. Nedeni ise dekardan alınan verimin düşük, masrafların yüksek olmasıdır.

\section{Bitkilerin Nispi Karı}

Bitkilerinin gayrisafi üretim değerinin toplam üretim masrafına oranı olarak elde edilen nispi kar Çizelge 2'de gösterilmiştir. Bütün bitkilerin nispi karı 1 ve üzeri olduğu için zarar etmemişlerdir. Nispi karı en yüksek bitki ana ürün dane mısır ve ana ürün pamuktur. Nispi karı en düşük bitki ise silajlık mısır 2'dir.

\section{Ürün Desenlerinin Ekonomik Açıdan Karşılaştırılması}

Ürün desenlerinin ekonomik açıdan karşılaştırılması Çizelge $6^{\prime}$ da verilmiştir. Çizelge $6^{\prime}$ da görüldüğü üzere ürün desenlerinin ekonomik açıdan karşılaştırılması yapıldığında gayri safi üretim değeri bakımından en yüksek veri 2058 TL/ da ile ikinci ürün pamuk + buğday desenidir. İkinci sırada ana ürün pamuk deseni $2044 \mathrm{TL} /$ da yer almaktadır. En düşük gayri safi üretim değeri $1137 \mathrm{TL} / \mathrm{da}$ ile ana ürün dane mısırdır.

Üretim masrafları yönünden en yüksek masraf $979.57 \mathrm{TL} / \mathrm{da}$ ile ikinci ürün pamuk + buğday ürün desenindedir. Üretim masrafı en düşük ürün deseni ise $350.44 \mathrm{TL} /$ da ile ana ürün dane misırdadır.

Bürüt kar bakımından en yüksek ürün deseni verileri 1300 $\mathrm{TL} / \mathrm{da}$ ile ana ürün pamuktur. Bunu 1124.5TL/ da ile ana ürün yer fıstığı izlemektedir. En düşük bürüt kar ise 785.5 $\mathrm{TL} /$ da ile ana ürün dane mısırdadır.

Çizelge 6. Ürün desenlerinin ekonomik açıdan karşılaştırılması

\begin{tabular}{lllll}
\hline Bitki & $\begin{array}{l}\text { Gayrisafi Üretim } \\
\text { Değeri (TL/da) }\end{array}$ & $\begin{array}{l}\text { Üretim Masrafı } \\
\text { (TL/da) }\end{array}$ & Brüt Kar (TL/da) & Nispi Kar \\
\hline Ana ürün pamuk & 2044 & 744.62 & 1300 & 2.74 \\
Ana ürün dane mısır & 1137 & 350.44 & 785.5 & 3.24 \\
Ana ürün yer fıstığı & 1792 & 667.48 & 1124.5 & 2.68 \\
İkinci ürün pamuk + Buğday & 2058 & 979.57 & 1078.4 & 2.10 \\
İkinci ürün dane mııır + Buğday & 1720 & 672.44 & 1047.4 & 2.55 \\
Silajlık mısır +Silajıık mısır + Fiğgarpa karışımı & 1911 & 957.88 & 953.12 & 1.99 \\
\hline
\end{tabular}

\section{SONUÇ}

Sonuç olarak denemenin ekonomik analizinde brüt karı en yüksek ürün deseni ana ürün pamuk olurken nispi karı en yüksek ürün deseni ise ana ürün dane mısır olmuştur. Ancak çalışmada tüm ürün desenlerinin nispi karı $1^{\prime}$ in üzerinde olmasından dolayı, üretici incelenen altı ürün deseninden de kar elde edilmektedir. Üreticiler incelenen ürün desenlerini münavebeli bir şekilde uygulamaları halinde
Nispi karı en yüksek ürün deseni, 3.24 değeriyle ana ürün dane mısırdır. Daha sonra en yüksek nispi kar ana ürün pamukta görülmektedir. En düşük nispi kar ise 1.99 ile silajık mısır + silajık mısır + fiğ-arpa karışımındadır.

Ürün desenlerinin ekonomik açıdan karşılaştırmasında; Candemir ve ark. (2017) 2014 yılında yaptıkları çalışmada dane mısır da GSÜD 702.56 TL/da ve pamukta GSÜD 910.78 $\mathrm{TL} /$ da olarak bulmuşlardır. Yine aynı denemede üretim masrafları mısırda $687 \mathrm{TL} /$ da, pamukta $856 \mathrm{TL} /$ da olarak bulmuşlardır. Yine Nispi kar açısından ele alındığında, mısırda nispi karı 1.01, pamuğun nispi karı ise 1.06 olduğu tespit edilmişlerdir. Çalışmada alınan nispi kar değeri 1 den büyük olduğu için elde edilen sonuçlarla uyum sağlamaktadır.

Paksoy ve Ortasöz (2018), yaptıkları çalışmada tanelik mısırda Gayri Safi Üretim Değeri 626 TL/da, üretim masrafı $539.85 \mathrm{TL} / \mathrm{da}$, bürüt karı da $185.4 \mathrm{TL} / \mathrm{da}$ olarak bulmuşlardır. Bürüt kar değeri pozitif yönde olmasına karşın elde edilen bulgulardan daha düşük ancak benzerlik göstermektedir.

Alemdar ve ark. (2014), yaptıkları çalışmada Brüt kârı birinci ürün mısır da $423.50 \mathrm{TL} /$ da, pamukta $165.15 \mathrm{TL} /$ da, buğday da $129.21 \mathrm{TL} /$ da ve ikinci ürün mısır da $169.86 \mathrm{TL} /$ da olarak hesaplamışlardır. Nispi kâr pamukta 0.97, ikinci ürün mısırda 1.10, birinci ürün mısırda 1.26 ve buğday da 1.19 olarak belirlemişlerdir. Çalışmada alınan sonuçlar pamuk haricinde 1 den büyük olduğu için elde edilen bulgularla uyum sağlamaktadır. Pamukta nispi karın 1 den küçük çıkmasının nedeni üretim girdilerinin yüksek, pamuk satış fiyatının düşük olmasıdır.

Yılmaz ve Gül (2016), pamukta yaptıkları çalışmada gayri safi üretim değeri $817.4 \mathrm{TL} / \mathrm{da}$, ortalama dekara pamuk verimi 391.3 kilogram ve nispi karı 1.02 olarak belirlemişlerdir. Çalışmada alınan sonuçlar elde edilen bulgularla benzerlik göstermektedir. hem toprak verimliliğini korunmuş olacak hem de karlı üretim yapmaya devam edebileceklerdir.

\section{KAYNAKLAR}

Akçaöz H (2001) Tarımsal Üretimde Risk, Risk Davranışları; Çukurova Bölgesi Uygulamaları. Doktora Tezi, Çukurova Üniversitesi, Adana.

Albayrak H (2014) Aydın Merkez Illçesi Pamuk Üretiminde Yetiştirme Koşullarının Verim, Lif Ve Tohum Özellikleri 
Üzerine Etkisi. Yüksek Lisans Tezi, Adnan Menderes Üniversitesi, Aydın.

Alemdar T, Seçe A, Demirdöğen A, Öztornacı B, Aykanat S (2014) Çukurova Bölgesinde Başlıca Tarla Ürünlerinin Üretim Maliyetleri ve Pazarlama Yapıları. Tepge Yayın No: 230, Ankara

Arslan S (2012) Farklı Fiğ (Vicia sativa L.) Arpa (Hordeum vulgare L.) Karışımlarının Verimi Ve Kalite Üzerine Etkisi. Yüksek Lisans Tezi, Selçuk Üniversitesi, Konya

Avcıoğlu Ş (1979) Çeşitli Fiğ+Arpa ve Fiğ+Yulaf Hasıllarının Verim ve Diğer Bazı Özellikleri Üzerinde Araştırmalar. Doktora Tezi, Ege Bölge Zirai Araşt. Ens, İzmir.

Candemir S, Kızılaslan N, Kızılaslan H, Uysal O, Aydoğan M (2017) Kahramanmaraş ilinde Dane Mısır ve Pamuk Üretiminde Girdi Gereksinimi ve Karlılıkları Açısından Karşılaştırmalı Analizi. Türk Tarım ve Doğa Bilimleri Dergisi, 4 (1), 1-8.

Egesel C, Kahrıman F, Tayyar \$̧, Baytekin H (2009) Ekmeklik Buğdayda Un Kakite Özellikleri İle Dane Ille Verimin Karşılıklı Etkileşimleri ve Uygun Çeşit Seçimi. Anadolu Tarım Bilimleri Dergisi 24(2):76-83.

Gündüz O, Esengün K (2007) Tokat İli Merkez İlçede Domates Yetiştiren İşletmelerin Risk Davranışına Göre Sosyo-Ekonomik Analizi. GoÜ. Ziraat Fakültesi Dergisi, 24 (1), 51-62

İdikut L, Kara S (2013) Tane Ürünü İçin Yetiştirilen İkinci Ürün Mısır Çeşitlerinin Bazı Verim Öğeleri İle Tane Nişasta Oranlarının Belirlenmesi. KSÜ Doğa Bilimleri Dergisi 16(1): 8-15.

Karademir Ç, Karademir E, Doran I, Altıkat A (2005) Diyarbakır Ekolojik Koşullarında Farklı Azot ve Fosfor Uygulamalarının Pamukta Verim ve Lif Teknolojik Özelliklere Etkisi. Gaziosmanpaşa Üniversitesi Ziraat Fakültesi Dergisi 22 (1): 55-61.

Kadiroğlu A (2012) Yerfıstığı (Arachis hypogaea L.) Yetiştiriciliğinde Farklı Çeşitler ve Sıra Üzeri
KALKINÇ M, KAYNAK MA

Mesafelere Göre Tek ve Çift Sıralı Ekim Yöntemlerinin Karşılaştırılması. Doktora Tezi, Süleyman Demirel Üniversitesi, Isparta.

Karaşahin M, Sade B (2011) Farklı Sulama Yöntemlerinin Hibrit Mısırda (Zea mays L. indentata S.) Dane Verimi ve Verim Unsurları Üzerine Etkileri. Uludağ Üniversitesi Ziraat Fakültesi Dergisi 25 (2): 47-56

Kaya M, Atak M, Çiftçi C, Ünver S (2005) Çinko ve Humik Asit Uygulamalarının Ekmeklik Buğday (Triticum aestivum L.)' da Verim ve Bazı Verim Öğeleri Üzerine Etkileri. SDÜ Fen Bilimleri Enstitüsü Dergisi, 9:3

Özçelik A, Fidan $H$, Albayrak M, Güneş E, Tanrıvermiş $H$, Gülçubuk B (2011). Tarım Ekonomisi. Anadolu Üniversitesi Açık Öğretim Fakültesi Yayınları. Eskişehir

Öztürk A, Bulut S, Boran E (2011) Bitki Sıklığının Silajlık Mısırda Verim ve Bazı Agronomik Karakterlere Etkisi. Atatürk Üniversitesi Ziraat Fakültesi Dergisi 39: 217224

Paksoy M, Ortasöz N (2018) Kahramanmaraş ili Pazarcık İlçesinde Mısır Üretim Faaliyetinin Ekonomik Analizi (2018) KSÜ Tarım ve Doğa Dergisi 21(Özel Sayı): 95101, 2018

Söğüt T (1996) Diyarbakır Şartlarında Ana Ürün Olarak Yetişebilecek Bazı Yerfıstığı (Arachis hypogaea L.) Çeşitlerinde Verim ve Bazı Tarımsal Özelliklerinin Belirlenmesi Üzerinde Bir Araştırma. Yüksek Lisans Tezi. Harran Üniversitesi. Şanlıurfa.

Uzun A, Karasu A, Turgut i, Çakmak F, Turan Z (2005) Bursa Koşullarında Ekim Nöbeti Sistemlerinin Mısırın Verim ve Verim Öğeleri Üzerine Etkisi. Uludağ Üniversitesi Ziraat Fakültesi Dergisi 19 (2): 61-68

Yılmaz Ş, Gül M (2016) İşletmelerde Pamuk Üretim Maliyeti, Karlılık Düzeyinin Değerlendirilmesi: Antalya ìli Örneği. Mustafa Kemal Üniversitesi Ziraat Fakültesi Dergisi 20 (2): 27-41 
